\title{
MIR107 Gene
}

National Cancer Institute

\section{Source}

National Cancer Institute. MIR107 Gene. NCI Thesaurus. Code C81774.

This gene is involved in the regulation of gene expression. While it has no known role in oncogenesis, MIR107 plays a role in the development of Alzheimer's disease. 